\begin{tabular}{|l|c|c|}
\hline $\begin{array}{l}\text { Word and Text } \\
\text { A Journal of Literary Studies and Linguistics }\end{array}$ & Vol. XI & $83-96$ \\
\hline
\end{tabular}

\title{
I Stink, Therefore I Mink: A Manifesto
}

\author{
Marie-Dominique Garnier
}

Université de Paris 8

E-mail: marie-dominique.garnier@univ-paris8.fr

\begin{abstract}
The recent mass culling of mink in Denmark and elsewhere, following the animals' contamination by a COVID-19 variant, is taken as a re-entry point into Derrida and Lacan's mink-mediated conversation in The Beast and the Sovereign. Out of the etymological 'stink' attached to the mink emerges an animot gifted with (unlimited) ink, with a potential to disturb philosophies of language, to write back or strike back, as it has recently done in the form of alignments of dead yet resurfacing animals. In the wake of Derrida's verbal disseminations around the vison, and of Lacan's attribution of a 'sort of language' to the animal in The Formations of the Unconscious, this essay follows an animal pack with includes the 17 million mink programmed for (double) extinction by inhumation and cremation. A hauntology follows, adumbrated by Lacan's interest in the 'secretion' of fur, mink oil and (psychoanalytic) sense, and by Derrida's encounter with the neoliberal, crypto-vison Alain Minc in 1994.
\end{abstract}

Keywords: animal turn, Jacques Derrida, Jacques Lacan, queer studies, fur farming, deconstruction, ecology of the mind, hauntology, politography, Alain Minc

'Man is not the only political animal $[\ldots]$ '. ${ }^{1}$

Is there, yet once more, something rotten in the Kingdom of Denmark? Before the start of the 2020 pandemic, the fur farming industry could claim to be bolstered by 'healthy' retail sales: the marketing of mink pelts was a thriving international affair, involving actors such as the American Mink Exchange or Kopenhagen Fur - in spite of what the US Fur Commission sought to discredit as the 'radical theocracy' ${ }^{2}$ of the Animal Rights movements. In the current context, the question is no longer whether or not to 'capitulat[e] to animal rights pressure campaigns'. ${ }^{3}$ A spectral moment may affect/infect the world of exchange, to quote the opening lines of Specters of Marx in which Jacques Derrida summons up, as an afterthought, the first words of the Manifesto of the Communist Party: 'A spectre is haunting Europe'. ${ }^{4}$ As in Shakespeare's Hamlet, 'prince

\footnotetext{
${ }^{1}$ Jacques Derrida, Limited Inc, trans. Samuel Weber (Evanston, IL: Northwestern University Press, 1988), 136.

${ }^{2}$ Fur Commission USA, 'U.S. Mink Farming Industry'; available at https://furcommission.com/furindustry-statistics/ [accessed 30 May 2021].

${ }^{3}$ Fur Commission USA, 'L.A. Should Scrap its Ban on Fur'; available at https://furcommission.com/l-ashould-scrap-its-ban-on-fur/ [accessed 11 June 2021].

${ }^{4}$ Karl Marx and Friedrich Engels, The Communist Manifesto, intr. David Harvey (London: Pluto Press, 2008), 31 .
} 
of a rotten state', 5 animal carcasses have left their graves to stand 'tenantless', like 'the sheeted dead [who] Did squeak and gibber in the Roman streets', dark precursors of 'feared events' to come. ${ }^{6}$

As a consequence of a program of massive animal extermination carried out in Denmark (and elsewhere) since December 2020, and the ensuing risks of soil contamination, voices have risen demanding the incineration of the dead animals. Deeming unsafe the initial burial methods used, Signe Munk, Member of Parliament for West Jutland and deputy for the Northern Green Left, described the situation as a 'ticking environmental bomb'. ${ }^{7}$ In the wake of their massive killing or 'culling', four million mink carcasses are scheduled to be unearthed in the summer of 2021 in North Zealand, after an initial test exhumation in May 2021 to assess the condition of the animals buried for over six months under a thin layer of soil and lime. The plan, according to local media, is for 'all animal carcasses to be dug up and incinerated by mid-July' before temperatures rise and odour nuisances threaten 'citizens in the areas near the mink' ${ }^{8}$

Citizens in the area near the mink? But what exactly is an area, what line (or lime) separates an 'area' from the 'air' within or around it? How near the mink are the citizens of the globalized minkdom of Denmark? How close to their cause is the politography of a proper name, the name of Signe Munk, whose mimetic, animalhaunted signature seems to carry out an act of ventriloquism or hauntography? How far do bad smells and polluted waters travel? What is the reach of a reek? And what does stench have to say that is not already inscribed in the signifier 'mink' itself - a name which in Danish (as in French) is a declaration of unbreathability, literally saying: I stink $?^{9}$ In 2021, the species' stigmatizing name speaks back, stinks back, resurfacing in the form of an unearthed, ashen collective. Ash will be 'there', disseminated, inhaled and portable - in and out of trashed animal bodies. Ashes, rather than cinders, Derrida writes, 'are the best paradigm for what I call the trace'. ${ }^{10}$

A limited number of minks appear in the penultimate lesson of Derrida's seminar on The Beast and the Sovereign. ${ }^{11}$ They make a late entrance, at a point when Derrida returns to Jacques Lacan's remarks on human language versus animal reflexes in The Formation of the Unconscious, and mentions mink farming. In a paronymic redeployment of the French word for mink, vison, Derrida introduces a pack of similarsounding terms - among which vision (sight), viser (to aim at) and an etymology-based

\footnotetext{
5 Jacques Derrida, Specters of Marx: The State of the Debt, the Work of Mourning and the New International, trans. Peggy Kamuf, intr. Bernd Magnus and Stephen Cullenberg (New York and London: Routledge, 2006), 2.

6 William Shakespeare, Hamlet, Prince of Denmark, ed. Philip Edwards (Cambridge: Cambridge University Press, 1985), I.i, 11. 115-16, 121.

${ }^{7}$ BBC News, 'Coronavirus: Calls in Denmark to dig up millions of dead minks' (27 November 2020); available at https://www.bbc.com/news/world-europe-55101058 [accessed March 12 2021].

${ }^{8}$ The Local, 'Denmark begins exhumation of four million dead mink' (13 May 2021); available at https://www.thelocal.dk/20210513/denmark-begins-exhumation-of-four-million-mink-carcasses/ [accessed 15 May 2021].

${ }^{9}$ Oxford English Dictionary, 2nd ed. (Oxford: Oxford University Press, 1989), s. v. 'Mink': 'Found in SW as (...) mânk,menk, "a stinking animal in Finland"".

10 'Introduction: Mourning Becomes Telepathy', in Jacques Derrida, Cinders, ed. and intr. Ned Lukacher (Lincoln, NE and London: University of Nebraska Press, 2014), 1.

${ }^{11}$ Jacques Derrida, The Beast and the Sovereign, Volume II, ed. Michel Lisse, Marie-Louise Mallet, and Ginette Michaud, trans. Geoffrey Bennington (Chicago, IL and London: University of Chicago Press, 2011), 246-9.
} 
array ranging from the organic chemistry of stink bombs (vesse: fart) to ill-smelling mushrooms known as vesses-de-loup (puffball fungi), in which a part-animal, partvegetal loup returns, as a kingdom-crossing animot. As a textual worker out on the trail of the vison, Derrida aims at (vise) Lacan, who finds himself annexed to the (dead) mink as an indicator of economic status, singled out for its weasel-like capacity to roam into suspicious areas of 'power' and danger zones involving the semantic fields of aggression, supervision and control. Yet Derrida's critical summoning up of Lacan involves, at the back of the mink that haunt both texts, strange becomings - the becoming-wild of a 'wild text', to borrow Jack Halberstam's phrase in Wild Things; in other words, 'a text that must remain unknown, unperformable, illegitimate, beyond classification'. ${ }^{12}$ Between two 'men', both of whom are 'talking mink', a queer scenario is carried out, using the animot as a relay. The volumes' initial formula - opposing 'the [feminine] beast and the [masculine] sovereign' ${ }^{13}$ - seems to be troubled in this particular scene. What gender is a mink? Who's playing mink? Who's writing in pink ink - or mink ink? Out of Derrida's scathing critique of Lacan emerges a troubled, gender-shifting scene, as well as a dark precursor of animal-rights/animal-writes. Having a mink on one's mind may induce boundary crossings and affects endowed with rebound effects on the human, textual handlers.

This article addresses the matter of animal rights and their proximity to how [an] 'animal writes'. ${ }^{14}$ It addresses the thinning limit between 'culling' and 'calling', between the scheduled unearthing of Danish mink and the political and onomastic resources of proper names - from Signe Munk to Alain Minc, about whom more later and between the ongoing, mink-minded, posthumous conversation that goes on between Lacan and Derrida, and the uncouth production of non-classifiable, roaming or volatile signifiers among human and non-human animals whose 'perturbed spirit' ${ }^{15}$, like the ghost of Old Hamlet, will not rest.

\section{Murder of Mink}

Whether recently buried, freshly exhumated or due to be incinerated, the cohorts of Danish mink will have their 'say', to pick up the first, performative syllable of 'And Say the Animal Responded?' 16 The 'culled' animals, killed for fear they might spread a mutated version of SARS-CoV-2 known as Cluster 5, have kept resurfacing from their graves literally as well as textually - as underground workers lined up under lime yet repeatedly returning to haunt the headlines, ${ }^{17}$ or as moles working ' $i$ 'th'earth so fast'. ${ }^{18}$

\footnotetext{
12 Jack Halberstam, Wild Things: The Disorder of Desire (Durham, CA: Duke University Press, 2020), 55 .

${ }^{13}$ Jacques Derrida, The Beast and the Sovereign, Volume I, ed. Michel Lisse, Marie-Louise Mallet, and Ginette Michaud, trans. Geoffrey Bennington (Chicago, IL and London: University of Chicago Press, 2009), 97.

${ }^{14}$ Marie-Dominique Garnier, 'Animal Writes: Derrida's Que Donc and Other Tails', in Demenageries. Thinking (of) Animals after Derrida, ed. Anne Emmanuelle Berger and Marta Segarra (Amsterdam and New York: Rodopi, 2011), 23-41.

${ }^{15}$ Shakespeare, Hamlet, I V 183.

${ }^{16}$ In Jacques Derrida, The Animal That Therefore I Am, ed. Marie-Louise Mallet, trans. David Wills (New York: Fordham University Press, 2008), 119-40.

${ }^{17}$ The Guardian, 'Pollution fears over mink buried after Covid culling in Denmark' (5 March 2021); available at https://www.theguardian.com/world $/ 2021 / \mathrm{mar} / 05 /$ pollution-fears-over-mink-buried-aftercovid-culling-in-denmark [accessed 15 May 2021].
} 
How are they responding? How does the recent killing of millions of minks respond to the relatively minor appearance of one mink towards the end of Derrida's The Beast and the Sovereign II and, much earlier, in Lacan's Seminar $V$ - hardly a cluster. How do they speak or write back to a philosopher and an analyst's reflections on animal semiotics/a-semiotics? Both texts can be revisited as wild, unstable performances belonging to a non-linear temporality, delivering a pre-pandemic, tentative ecology of mink - more to follow, in the footprints of Bateson's Ecology of Mind.

Denmark, November 2020: alignments of decaying bodies get 'pushed out of the ground' due to expanding volumes of nitrogen and phosphorus gases formed during the decomposition process. ${ }^{19}$ December 2020: mink corpses become water pollutants as their decomposing bodies start to leek juices into the ground. ${ }^{20}$ The mink, in other words, become manifest; they write a macabre, text-like manifesto made of grim lines on the ground; they creep back from their burial alignments or seep into the water supplies, turning into grisly, underground agents of Zygmunt Bauman's liquid society. Zombie-minks are responding, from their angle, to man flu - rather than a zoonotic disease. Their undead voices may also respond through human voices, and cause interference with human decision-making on environmental matters. Denmark's recent sanitary politics have been haunted, or occupied, by an underground/underwater Mink Parliament. The animals have become part of a legal controversy about unsafe burial methods, testifying to the fact that 'man' does not inhabit what can safely be termed an 'environment'. Human matters and mink matters mingle beyond man's failed attempts at prevention via the prophylactic use of barrier terms - such as 'farming' used in industrial mink farming, implying that animals are farmed like crops. It was, precisely, the Danish Agriculture Minister, Mogens Jensen, who resigned 'in the furore' over the government's legal basis for the cull. ${ }^{21}$ Has 'fur' finally managed to strike back and infect human language with a furry syllable from the Latin furore? Have minks become, at the back of men's 'minds', the collective name of a suppressed, guilty voice bound to return in furtive, unpredictable ways?

Following the scent of Derrida's troubled lines and limitrophies in The Beast and the Sovereign, it would be a mistake to separate one Parliament from another. The culled animals - in which the gesture of culling seems as innocent as flower-picking or lawn-mowing - cannot be separated from a post-mortem call: an outcry, an underground murmur reaching far and wide beyond the boundary between buried bodies and a body elect. If a group of owls can be termed a 'parliament', ${ }^{22}$ so can a group of mink, whether dead, living, incinerated or resurfacing once buried. A Mink Parliament might have things to say or to gainsay when responding to human policies regarding the European farming of animals for fur - in spite of 'humane' attempts to treat exploited animals fairly by simply choosing to rename their welfare 'wellfur'. ${ }^{23}$

\footnotetext{
${ }^{18}$ Shakespeare, Hamlet, I.v.1. 162.

${ }^{19}$ The Guardian, 'Culled Mink rise from the dead to Denmark's horror' (25 November 2020), available at https://www.theguardian.com/world/2020/nov/25/culled-mink-rise-from-the-dead-denmark-coronavirus [accessed 16 May 2021].

${ }^{20}$ Reuters, 'Mass mink graves in Denmark may have soiled groundwater' (10 December 2020); available at https://www.reuters.com/article/health-coronavirus-denmark-mink/mass-mink-graves-in-denmarkmay-have-soiled-groundwater-report-idUSKBN28K14N [accessed 15 May 2021].

${ }^{21}$ BBC News.

${ }^{22}$ James Lipton, An Exaltation of Larks (London: Penguin, 1968).

23 Tine Rousing, Steen Henrik Møller and Steffen W. Hansen, 'WelFur-mink: on-farm welfare assessment of mink (Neovision vision) - effect of sample size on animal-based measures' (2021);
} 
Denmark's twice-exterminated (buried and burnt) mass of mink challenges Derrida's anthropological reflexions on the separation between two distinct human burial practices in the last pages of The Beast and Sovereign. Twice eliminated, first by inhumation then by incineration, the mink manifest a form of 'rite' in excess; twice negated yet possibly not quite dead yet, they may be writing a parodic accelerationist manifesto, in keeping with the collapse of economic paradigms and neoliberal projects. Their elimination to the power of two renders obsolete the anthropological and philosophical line on which Derrida concludes his seminar. The surplus value of ritual behaviours matches the 'new breed of cataclysm' described in Williams and Srnicek's manifesto, ${ }^{24}$ in contradiction with Derrida's distinction between 'les incinérants' and 'les inhumants', inhumation and cremation. ${ }^{25}$

Like a multitude of crows, minks are part of a crowded multiplicity: they form a collective whose name may be re-spelt and re-inscribed as murder in both senses of the word: a collective noun for a pack of animals, such as crows, and a quick, inconclusive method of disposal - out of which they can quicken back to life. The mink-murder haunts a troubled threshold between the living and the dead, between response and responsibility.

The question of animal response or of animal reaction comes up in several of Derrida's texts on the animal following Bentham's reflexions, but also, much earlier, in Lacan's Seminar $V-$ a text which beneath its apparent clear-cut distinctions (such as between human language and animal code) leaves a number of loose threads hanging, ready to resurface. Derrida's 2003 re-reading of Lacan's Seminar $V$ can be approached not only for what it has to say or write about the mink and in particular about its French lexical variety (vison), but also for its instable, mutant forces. In an earlier session Derrida had found fault with Lacan for dealing with the animal in the singular, and objected to the "whole traditional discourse on "the animal" (as though any such thing could exist in the singular)'. ${ }^{26}$ Yet against the grain of his critique Derrida had also read 'earlier texts of Lacan's' as much less stable, texts that 'simultaneously announced a theoretical mutation and a stagnant confirmation of the legacy, its presupposition and its dogmas ${ }^{27}$ - i.e. the dogma that an animal cannot become a subject of the signifier, and therefore cannot respond but only 'react'. ${ }^{28}$ Yet even when dealing with Lacan's commentaries on the dance-language or 'dancity' of bees, the ability to feign and lure in dance in a system of coded signs without language, Derrida concludes that Lacan sees the animal as forever caught up in the logic of 'vital situations', therefore incapable 'of an authentic relation to death' ${ }^{29}$ - all the while recalling more undecidable moments in Écrits, in which a beast enters 'into relations with the Other [...] to the extent of its illness, the neurotic defect that brings it closer to man'. There is, to quote Lacan, no

available at https://www.semanticscholar.org/paper/WelFur-mink\%3A-on-farm-welfare-assessment-ofmink-of-Rousing-M\%C3\%B81ler/06c5f2db73e2499bfd2b0c238cfa367bf81a3f29 [accessed 12 March 2021].

${ }_{24}$ Alex Williams, Nick Srnicek, '\#Accelerate Manifesto', available at https://criticallegalthinking.com/2013/05/14/accelerate-manifesto-for-an-accelerationist-politics/

[accessed 13 June 2021].

${ }^{25}$ Derrida, The Beast and the Sovereign I, 167.

${ }^{26}$ Derrida, The Beast and the Sovereign I, 56.

${ }^{27}$ Derrida, The Beast and the Sovereign I, 112-13.

${ }^{28}$ Derrida, The Beast and the Sovereign I, 117.

${ }^{29}$ Derrida, The Beast and the Sovereign I, 172-3. 
'discontinuity between animal and human psychology'. ${ }^{30}$ Although, as Derrida claims, Lacan's approach is placed under the sign of the Cartesian cogito, tied to a Cartesian $I$ think, what happens when illness brings men and non-men, man and mink, in close viral contact? What happens when 'stinking' colonizes thinking? Or when the distinctions between making/effacing tracks, between tracks and traces, 'dumb' animals and human dweebs, no longer hold? When the dumb can be unmuted via mutational processes? Both Lacan and Derrida bring up concepts of vulnerability and fragility in relation to the effacement of tracks and traces. For Derrida, 'it is not in the power of anyone to efface [a trace] or above all to "judge" as to its effacement'. ${ }^{31}$ The double session of extermination to which 17 million mink have been submitted is not only a succession of mistakes, a stuttering form of utterance. It also challenges classic approaches to the concept of 'environment' as an externalized, differential sphere - a challenge best rendered perhaps in Derrida's formulaic phrase: 'Lacan talks "mink", ${ }^{32}$ What is happening to 17 million mink is a grim repetition of Derrida's 'trace' and Lacan's 'signifier', respectively rewritten as two processes of effacement: to trash, to (s)ignify and turn to ash.

\section{Speaking in A Furry Tongue}

From the farmed animals' second rising emerges a dumb soundtrack that renders fragile and shaky the boundaries, the barrier gestures of language that insist on isolating the sovereign from the beast, or, to take up The Beast and Sovereign's first semi-articulate sounds, the gender barriers erected between $l a$ and $l e$. Contained in the logos and logic of the boundary, a bound- is on the lookout, alert; one or several bounds can be followed in the strange dance or pas-de-deux, the dance duet of Derrida's penultimate seminar on Lacan's Seminar V-about which more later.

How would a multitude of talking mink respond? How would they speak, like the ghost of Old Hamlet, with their 'beaver [visière] up'? How would they write? Say the mink responded? Cooped and schooled on fur farms, the animals might have gained some language training from their handlers: they might have caught, like one catches an airborne virus, floating fragments of an elementary, semi-articulated tongue; or have inferred (infurred?) a few basic rules of textuality based on day-long proximity with straight lines (no different from alignments of coops and corpses) and on the grid patterns of battery cages. Some mink may have acquired the ability to utter. A mink is a stink is athink is athought. A scent is a sense is a whiff is a stiff. An osmic soundtrack in minkspeak may make nose-sense as well as no-sense. Given proper odorivectors, a scent is as good as sentient; sentience is as good as sentence. Fur may deliver a soft, inaudible furry tongue, doubling as the tongue of a furry animal and as the hairy, uncertain, coated organ of a sick body, contributing to the production of signifiers and symptoms rather than coded signs. A variant of that furry tongue can be found locally at work in Derrida's approach of Lacan, and in the one-sided conversation that goes on between Derrida and the psychoanalytic sovereign/animal in the process of being textually (man)handled.

\footnotetext{
${ }^{30}$ Derrida, The Beast and the Sovereign I, 129.

${ }^{31}$ Derrida, The Beast and the Sovereign I, 131.

${ }^{32}$ Derrida, The Beast and the Sovereign II, 246.
} 
Lacan re-enters Derrida's penultimate seminar of March 2003 in connection with minks - in the plural. This late reappearance involves a major change. Lacan returns, not only as the classic figure of a traditional language philosopher (a 'sovereign'), true to his previous appearances throughout the seminar, but also as a territorial, fur-clad, alpha-beast, subjected to a double moment of seduction and confrontation -with no ability to respond. Readers/listeners in ambush may have caught a glimpse of his name in the book's initial mumblings - its gender-based blueprint: $l a \ldots l e .{ }^{33}$ In this minimal bear-trap Derrida's hand captures the passing figure of Lacan. In the space of an initial lure, two alpha-animals might covet the cramped ground of a ' $l a$ ' - Lacan's feminizing syllable and Derrida's là or -da. ${ }^{34}$ Derrida's game of dethronement follows a strange, unpredictable path, as the book's previous critique of Lacan bifurcates into a seduction parade.

The extended textual excepts from Seminar $V$ which Derrida reads and comments at length contribute to the production of yet another Lacan: a Lacan-in-fur, a sovereign as well as an animal, a $l a$ as well as a $l e-$ a (la)canine rodent whose underground territories Derrida is leisurely visiting and reclaiming. This strange encounter with Lacan gives flesh to one of Derrida's gender games in volume I: an ' $i$ ' here literally mutates into 'une il': 'how do you write "il(e)"?'. ${ }^{35}$ La ...le initiates a gender-troubled tongue as well as lalling, a phonetic moment, perhaps in imitation of lalangue - a term Lacan chose for its proximity to lallation, ${ }^{36}$ the lull of a mother tongue. At the opposite end of the seminar, minks - mean mammals in soft fur - take over. The final k- sound common to milk and mink, with its portable cutting machine, resonates in Lacan's animalized, non-binary scenario of man's acquisition of language, staged in Plato's real or imaginary cave:

\begin{abstract}
Man has been crying for a long time, like any other one of those little animals who mew for their mother's milk. But to notice that he is capable of doing something, which of course he understands for a long time - because in the babbling, in the confusion, everything happens - but in order to choose, he must have noticed that K's resonate better from the back, the back of the cave, and that B's and P's come out better at the entrance, this is where he heard their resonance. ${ }^{37}$
\end{abstract}

Speaking of a mammal's craving for 'lait' (which he sees as the source of early mewlings in men and critters), Lacan laterally moves on to 'letters' - in particular to the letter $\mathrm{k}$ which, he explains, resonates from the remotest corner of Plato's cave, a blueprint for the buccal cavern and its 'furthest wall'. Resonance becomes, a few paragraphs further, a substitute for reason - in Francis Ponge's spelling réson. ${ }^{38}$ Within a mink's minimal consonantal frame, ink resonates - of more than one ilk, from the

\footnotetext{
${ }^{33}$ Derrida, The Beast and the Sovereign I, 19.

${ }^{34}$ Marie-Dominique Garnier, "“Ce Da, ce là”: les noms-dits', Le Tour critique 3 (2011); available at http://letourcritique.u-paris10.fr/index.php/letourcritique/article/view/78/html [accessed 16 June 2021].

${ }^{35}$ Derrida, The Beast and the Sovereign II, 3.

${ }^{36}$ Danielle Treton, 'La lalalangue', Insistance 5.1 (2011): 163-9.

37 Jacques Lacan, The Knowledge of the Psychoanalyst 1971-1972, trans. Cormac Gallagher, available at http://www.lacaninireland.com/web/wp-content/uploads/2010/06/Book-19a-The-Knowledge-of-thePsychoanalyst-1971-1972.pdf [accessed 14 June 2021]. In French, Lacan uses the verb 'vagir' for humans and animals alike - when crying for their 'mother's milk' or 'lait maternel'. Je parle aux murs. Entretiens de la Chapelle Sainte-Anne (Paris: Seuil, 2011), 89.

${ }^{38}$ Lacan, Je parle aux murs, 93.
} 
corporate inc. of Alain Minc's proper name, with whom Derrida shared the textual space of Penser ce qui vient, to pornographic minks.

The ink that flows in the writing of The Beast and Sovereign follows in the steps of a $l a-$ a note, an article, a feminine motive, a trace under erasure, and the first syllable of Lacan's name. What lurks in the philosopher's approach is ready to pounce at the Lacanian pelt in a gesture of performative violence. Lacan's Seminar $V$, which Derrida quotes at length, performs a double scene, first by drawing a clear-cut line of separation between signifying humans and signalling non-humans, then by elaborating on minks, taken as an example of animal response, animals responding when spoken to, whose fur improves whenever they receive the benefit of a conversation from their handlers. Contrary to what might be expected, that conversation involves more than mere signals and seems to imply minimal signifiers. This time, contrary to Derrida's earlier claim, ${ }^{39}$ Lacan is dealing with animals in the plural, not in the abstract. It is interesting, besides, to compare Lacan's original to Derrida's own quoted version which twice omits a significant typographic detail. In the original Lacan italicizes two words, neutralized in the published version of La Bête et le souverain, both in French and in English: ${ }^{40}$

So we have heard it said that mink held captive with lucre in mind, namely to make a profit from their fur, waste away and give only a mediocre product to the furrier if he does not make conversation with them. It appears that this makes the farming of mink very expensive by raising the general cost. (...)

From there, I'd simply like to move on to show you the direction in which we can refer our problem to Pavlovian studies of conditioned reflexes. In the end, what are conditioned reflexes? (...)

All those little electric signals, those little bells and ringers they use to deafen the poor animals to get them to secrete to order their various physiological products, their gastric juices, are all the same clearly signifiers and nothing else. ${ }^{41}$

Two verbs italicized in Lacan's original text poke their mink noses up and out of textual immobilization: to tympanize, to secrete. 'Tympanize' has literally been deafened in translation, ${ }^{42}$ which somehow misses the connecting link (or the connecting mink) with Derrida's intensive use of the term in the opening pages of Margins of Philosophy. Secrete, which Lacan associates with the production of a full-fledged or full-pelted signifier, is also interesting in that it ties two ends, physiology and linguistics, blurring

\footnotetext{
${ }^{39}$ Derrida, The Beast and The Sovereign I, 56.

40 The translator of The Beast and The Sovereign has also translated Derrida's quotations from Lacan's Les Formations de l'Inconscient (1957-1958). See The Beast and the Sovereign II, 236, n. 6.

${ }^{41}$ The Beast and the Sovereign II, 250. Cf. the original text of Lacan's Le séminaire V: 'Nous nous sommes laissé dire que les visons captifs dans le dessein de lucre, à savoir pour tirer profit de leur fourrure, dépérissent et ne donnent que d'assez médiocres produits aux pelletiers si on ne leur fait pas la conversation. Cela rend, paraît-il, l'élevage des visons très onéreux en accroissant les frais généraux. [...] Pour tout dire, je voudrais simplement vous indiquer le rapport, la direction dans laquelle nous pouvons voir, en rapport à notre problème, les études pavloviennes des réflexes conditionnés. En fin de compte, qu'est-ce que c'est que les réflexes conditionnés ? [...] Tous ces petits signaux électriques, ces petites sonnettes, ces petites clochettes, dont on tympanise les pauvres animaux, pour arriver à leur faire sécréter leurs diverses productions physiologiques, leurs sucs gastriques aux ordres, ce sont quand même bien des signifiants, et rien d'autre.

${ }^{42}$ Here is the published translation of Lacan's Seminar $V:$ ' $(\ldots)$ All the little electrical signals, the little buzzers and little bells which are drummed into the poor animals so as to make them secrete, on command, their various physiological productions, their gastric juices - they are all actually signifiers, really, and nothing but'. Formations of the Unconscious. The Seminar of Jacques Lacan, Book V, ed. Jacques-Alain Miller, trans. Russell Grigg (Cambridge: Polity Press, 2017), 319.
} 
the difference between signals and traces. The mink's production of quality pelts and bodily fluids (mink oil) is a form of secretion, but so is the ability of make sense. 'To secrete' returns in Lacan's address to younger analysts in Je parle aux murs:

[...] I absolutely do not believe in common sense. There is sense, but there is no common one. There is probably not one among you who understands me in the same sense. Moreover, I strive to ensure that access to this sense is not too easy, so that you have to put something of yourself into it, which is a salubrious and even therapeutic secretion. Secrete sense vigorously and you will see how much more easy life will become! ${ }^{43}$

Making sense amounts to 'minking' sense: to secreting, sending shoots, producing fluids, moving quickly, inventing oily, inky, or well-oiled connections, or possibly speaking in a minor lalangue or a trans-linguistic langue d'oil. In the above quotation Lacan occupies the position of a handler or furrier, engineering or encouraging 'therapeutic secretions', not from minks but from shrinks - an audience of younger analysts on a training course. Making sense involves co-elaboration with a secreting, productive counterpart. Like mink oil or mink-ink, it results from a many-sided conversation - one which Derrida redirects and secretes otherwise in The Beast and The Sovereign, to produce an instable or wild text. There is no telling to which temporality a wild text belongs.

\section{Of Minks and Men}

Derrida is chasing out one particular word in Lacan's minkspeak: the word lucre, which positions Lacan on the wrong side of France's political map, rubbing elbows with the well-off, the bigoted or the right-wing conservatives - such as Jean-Pierre Raffarin, one of the least popular French Prime Ministers, whose typical catch-phrases such as 'France d'en haut/France d'en bas' Derrida ironically recirculates. 'Lucre', or the passion for gain, is redirected from the semantic field of the luxury fur industry to reflect back on psychoanalysis as accessible to an upper 'tier' of privileged individuals.

On the other hand, lucre can be re-signified and made to produce new connections and secretions: it may be a symptom, the soundtrack of an animal's name, the genderfluid name of one of the cats that lived with the Derrida family, the Siamese 'buried in the garden of Derrida's home in Ris-Orangis', a cat who seems to return in Tourner les mots 'like a return of the ghost of Lucrece'. ${ }^{44}$ With or without Lucrece, Derrida's reading of Lacan produces a spectrum of gender-fluid slippages and moments of instability. A becoming-mink (via Lacan's own interest in the production of fur as a form of secretion) is doubled with a becoming-woman, or possibly with a collateral becoming-minx - which requires little to no effort to resurface. Unrelated to minkwearing, no 'minx' actually stars in Derrida's seminar, articulated on one single mink as opposed to Lacan's collective, farmed minks. However, the signifier - or queer animot - 'minx' seems to follow in the steps of textual and furry minks, suspended between two etymologies: a mynx: a pet-dog, and a minnikin: a term of endearment for a woman. Vison not only emits a form of class hatred vis-à-vis psychoanalysis: it allows

\footnotetext{
$43 \mathrm{http} / /$ www.lacaninireland.com/web/wp-content/uploads/2010/06/Book-19a-The-Knowledge-of-thePsychoanalyst-1971-1972.pdf [accessed 12 May 2021].

${ }^{44}$ Peggy Kamuf, 'Stunned: Derrida on Film', in To Follow: The Wake of Jacques Derrida (Edinburgh: Edinburgh University 2010), 118.
} 
entry into other semantic fields. Beyond class issues and the sociology of neoliberal France under right-wing rule, 'vison' is reconnected to downward mobility, whether social or bodily. Derrida insists on placing the animal in phonetic touch with 'vesse' (flatulence) and the foul-smelling, ground-level mushroom: the vesse de loup, thus directing attention below waist-level after recruiting a pair of nouns in the feminine (' $l a$ vesse' and 'la vesse-de-loup' as opposed to 'le vison'); both nouns precede the seminar's approach of Lacan, whose name is trapped and contaminated by the feminized and foul-smelling drift of Derrida's thoughts. Staged across Derrida's disseminated remarks is a queer or drag-moment, which shuffles and multiplies the polarities established in the book's initial binary la/le. Sprinkled among Derrida's apparently disconnected references and quotations from the Littré dictionary, one finds a sentence from La Fontaine, about neighbours living across from each other (vison$v i s u$ ) and 'squabbling about their wives'; another one from Madame de Sévigné who mentions a 'Mr. de la Trousse', at which one may prick one's psychoanalytic ears for onomastic reasons (trousser: to truss/to possess sexually); and, finally, the stereotypical mention of women and fur ('rich clothing, preferably feminine') to which yet another dictionary quotation in the feminine is added: 'she bought herself a mink coat'. ${ }^{45}$ Lacan's mink talk enters immediately afterwards, as one more alternately-gendered addition to the list, to the effect that both 'men' interact through the furry relay of the minks (or (as) minx). Beyond the implicit power game and the displaceable gender performance (la/le), minks come back with Lacan as a pack formation: in the plural - as opposed to Derrida's single specimen. In this queer moment between two 'men', one of whom drags up the other into a luxury or luxurious figure, the mink operates as a textual toy or prosthetic animot running back and forth between le- and la/La, Derrida and Lacan. The vision-bound phenomenology of the 'vison' gives way to the queerer phenomenology of a stinking field, connected to the 'anal terror' ${ }^{\text {' }}$, the reek of a vesse, in its organic, animal, fungal dislocations. In the ecology of mink, as in Gregory Bateson's 'ecology of mind', 'we are not outside the ecology for which we plan' ${ }^{47}$.

\section{Neovison Vison: Derrida in Conversation with Alain Minc}

One textual/animal detail has been left unattended so far. Just before reading the lengthy excerpt from Lacan, Derrida alludes to the mink as a 'little carnivorous, especially North American mammal sought after by the rich on high. ${ }^{48}$ Why give the mammal a habitat rather than a name - North America? The long and slender body of the American mink is indeed sought after for its dark brown, quality fur, and mink trapping, as well as farming has been an ongoing business in North America, where 'one mink represents a pretty good day's work at the price they are selling now'. ${ }^{49}$

On the other hand, Derrida may be reactivating the memory of a conference in North America: the memorable encounter with Lacan at the Baltimore symposium in 1966, which perhaps accounts for his aggressive biting back in the Beast and Sovereign,

\footnotetext{
${ }^{45}$ Derrida, The Beast and the Sovereign II, 248-49.

${ }^{46}$ Paul B. Preciado, 'Anal Terror', in baedan 3 - journal of queer time travel (Seattle, WA: Contagion Press, 2015), 123.

${ }^{47}$ Gregory Bateson, Steps Towards an Ecology of Mind (Northvale, NJ: Jason Aronson Inc, 1972), 353.

${ }^{48}$ Derrida, The Beast and the Sovereign II, 249.

${ }^{49}$ A[rthur] R[obert] Harding, Mink Trapping: A Book of Instruction Giving Many Methods of Trapping An Invaluable Guide for Trappers (Columbus, OH: Harding Publishing Co, 1906), 95.
} 
mixed with memories of other misunderstandings and misrecognitions. Derrida's verbal stink attack may be a belated response to that memorable scene when Lacan had set the fur flying. ${ }^{50}$

The North American mink trail could also be pursued in another direction. In 1994, a few years after the 'Fall' of the Berlin Wall in November 1989 which coincided with the passage of the North American Free Trade Agreement, with financial deregulation and the emergence of neoliberalism, Derrida revised ontologies into hauntology, opening the gates to ghosts and their capacity to return without warning. Hauntology implies a non-linear conception of time and history, in other words the possibility of what could be called Danish time or Hamlet's Hour: a time 'out of joint', in which one burial will not suffice - mink will have to die another day. Taxonomically, the North American mink used to be placed alongside its European counterpart - in the genus Mustela. ${ }^{51}$ Its 1997 reclassification as Neovison vison gives the North-American animal a 'neo' prefix which resonates with Derrida's scathing critique of 'lucre' in The Beast and Sovereign. Out of the neo-ness of the mink's new taxon, two paratextual symptoms emerge: an exchange of neoliberal, 'limited inc.' or ink, and a proper name: A. Minc.

When Derrida discusses the writings of Alain Minc on the occasion of a joint presentation at the Sorbonne on 18 January 1994, followed by their joint publication Penser ce qui vient, both speakers have been preceded by their respective, previous publications: Specters of Marx and Le Nouveau Moyen-Âge. Although Derrida notes that he agrees to most of Minc's historical and political analyses, to the laws of acceleration to which time is submitted and to Minc's general politography, he distances himself from Minc's politology, objecting in particular to Minc's Cartesian frame of thought and to the idea that the law of the market is a 'natural' law. In the first paragraphs of Minc's answer to Derrida's critique emerges a quasi-behavioural, binary response opposing two orbits of thinking - a 'higher' versus a 'lower' orbit on which he places himself after having generously relegated the philosopher to the 'higher' orbit to the effect of removing him from the political picture and locking him up in the aloofness of some immaterial philosophical closet. Minc's promise to meet his interlocutor more than halfway shifts into the language of seduction between men: 'our words will meet, will cover one another'. ${ }^{52}$ Not only is this text a pre-run or prequel to the penultimate session of The Beast and The Sovereign - in which Derrida recycles the high vs low opposition and displaces it towards Lacan. It releases one of Derrida's keyconcepts, the idea of messianicity without messianism, the readiness to acknowledge what/who comes in a tongue which awaits its translations to come. Minks may be returning, with a vengeance, beneath Minc's name (shortened and Frenchified from Minkowski) to deliver one or more tongue-tied messages of 'afterlife' in animal ink.

\footnotetext{
${ }^{50}$ Michael Lewis, Derrida and Lacan: Another Writing (Edinburgh: Edinburgh University Press, 2008), 267.

${ }^{51}$ Larisa E Harding, Felisa A. Smith, 'Mustela or Vison? Evidence for the taxonomic status of the American mink and a distinct biogeographic radiation of American weasels.', Molecular Phylogenetics and Evolution $52.3 \quad$ (2009): 632-42, available at https://www.researchgate.net/publication/222140720_Mustela_or_Vison_Evidence_for_the_taxonomic_s tatus_of_the_American_mink_and_a_distinct_biogeographic_radiation_of_American_weasels; accessed 16 June 2021.

52 Jacques Derrida, Alain Minc, Penser ce qui vient (Paris : Le Nouveau Monde, 1994), 45. Translation mine.
} 
The ink of minkspeak must extemporize in a makeshift or minkshift manner, feeding on whatever comes near at hand or under webbed feet, as in the following sample, a collection of ashen fragments and uncertain, airborne animal voices. Is it the utterance of an otter? Or the letter of a lutra (as in lutra canadensis)? Webbed traces of Cixous's or Dante's lonza may be overheard, freshly escaped from the Inferno or the infurno of mink farms: 'We're minks. We're back. We're out on the skreets. Dweebmen kantkill us. You burnus you breathus. Haf dead haf alive. Ask minkash. A mink is a stink is a lonza. Una lonza leggera e presta molto, che di pel macolato era coverta' ${ }^{53}$

\section{Bibliography}

1. Bateson, Gregory. Steps Towards an Ecology of Mind. Northvale, NJ: Jason Aronson Inc, 1972.

2. BBC News. 'Coronavirus: Calls in Denmark to dig up millions of dead minks'. 27 November 2020. Available at https://www.bbc.com/news/world-europe-55101058. Accessed 12 March 2021.

3. Cixous, Hélène. Neuter. Translated and with an introduction by Lorene M. Birden. Lewisburg, PA: Bucknell University Press, 2004.

4. Dante Alighieri. The Divine Comedy of Dante Alighieri. Volume I. Inferno. Edited and translated by Robert M. Durling, Oxford: Oxford University Press, 1996.

5. Derrida, Jacques. The Animal That Therefore I Am. Edited by Marie-Louise Mallet. Translated by David Wills. New York: Fordham University Press, 2008.

6. Derrida, Jacques. The Beast and the Sovereign, Volume I. Edited by Michel Lisse, MarieLouise Mallet, and Ginette Michaud. Translated by Geoffrey Bennington. Chicago, IL and London: University of Chicago Press, 2009.

7. Derrida, Jacques, The Beast and the Sovereign, Volume II. Edited by Michel Lisse, MarieLouise Mallet, and Ginette Michaud. Translated by Geoffrey Bennington. Chicago, IL and London: University of Chicago Press, 2011.

8. Derrida, Jacques. Cinders. Introduced by Ned Lukacher. Lincoln, NE and London: University of Nebraska Press, 2014.

9. Derrida, Jacques. Limited Inc. Translated by Samuel Weber. Evanston, IL: Northwestern University Press, 1988.

10.Derrida, Jacques. Specters of Marx: The State of the Debt, The Work of Mourning and the New International. Translated by Peggy Kamuf. With an Introduction by Bernd Magnus and Stephen Cullenberg. New York: Routledge, 1996.

11.Derrida, Jacques, and Alain Minc. Penser ce qui vient. Paris: Le Nouveau Monde, 1994.

12.Fur Commission USA. 'L.A. Should Scrap its Ban on Fur'. Available at https://furcommission.com/l-a-should-scrap-its-ban-on-fur/. Accessed 11 June 2021.

13.Fur Commission USA. 'U.S. Mink Farming Industry'. Available at https://furcommission.com/fur-industry-statistics/. Accessed 30 May 2021.

14.Garnier, Marie-Dominique. 'Animal Writes: Derrida's Que Donc and Other Tails'. In Demenageries: Thinking (of) Animals after Derrida. Edited by Anne Emmanuelle Berger and Marta Segarra. Amsterdam and New York: Rodopi, 2011.

\footnotetext{
${ }^{53}$ Several voices invite themselves in minkspeak: traces of slang, Black American English, and the patter of Cixous's lonza whose furry body runs across Neuter, trans. and intr. Lorene M. Birden (Lewisburg, PA: Bucknell University Press, 2004 [1972]), 118: 'younger than ever, superb, wet, but as impregnable as the subject of the statement'. Cixous imports it from Dante's furry Inferno, Canto I, 32-33 (The Divine Comedy, Volume I, ed. and trans. Robert M. Durling [Oxford: Oxford University Press, 1996], 28.)
} 
15.Garnier, Marie-Dominique. “"Ce Da, ce là”: les noms-dits', Le Tour critique, n³ (2014)./ Available at http://letourcritique.u-paris10.fr/index.php/letourcritique/article/view/78/html. Accessed 16 June 2021.

16.Halberstam, Jack. Wild Things: The Disorder of Desire. Durham, CA: Duke University Press, 2020.

17.Harding, Larisa E, and Felisa A. Smith. 'Mustela or Vison? Evidence for the taxonomic status of the American mink and a distinct biogeographic radiation of American weasels'. Molecular Phylogenetics and Evolution 52.3 (2009): 632-42. Available at https://www.researchgate.net/publication/222140720_Mustela_or_Vison_Evidence_for_the_ taxonomic_status_of_the_American_mink_and_a_distinct_biogeographic_radiation_of_Am erican_weasels. Accessed 16 June 2021.

18.Jabre, Elias 'Pour une autre politologie'. Chimères 98 (2021): 73-91.

19.Kamuf, Peggy. 'Stunned: Derrida on Film'. In To Follow. The Wake of Jacques Derrida. Edinburgh: Edinburgh University 2010.

20.Lacan, Jacques. Formations of the Unconscious: The Seminar of Jacques Lacan, Book V. Edited by Jacques-Alain Miller. Translated by Russell Grigg. Cambridge: Polity Press, 2017.

21.Lacan, Jacques. Je parle aux murs. Entretiens de la Chapelle de Sainte-Anne. Paris: Seuil, 2011.

22.Lacan, Jacques. The Knowledge of the Psychoanalyst 1971-1972. Translated by Cormac Gallagher (6.1.1972, III.6). Available at http://www.lacaninireland.com/web/wpcontent/uploads/2010/06/Book-19a-The-Knowledge-of-the-Psychoanalyst-1971-1972.pdf Accessed 12 May 2021.

23.Lewis, Michael. Derrida and Lacan: Another Writing. Edinburgh: Edinburgh University Press, 2008.

24.Lipton, James. An Exaltation of Larks. London: Penguin, 1968.

25.Marx, Karl and Friedrich Engels. The Communist Manifesto. With an Introduction by David Harvey. London: Pluto Press, 2008.

26.Harding, A[rthur] R[obert]. Mink Trapping: A Book of Instruction Giving Many Methods of Trapping - An Invaluable Guide for Trappers. Columbus, OH: Harding Publishing Co, 1906.

27.Preciado, Paul B. 'Anal Terror'. In bcedan 3 - journal of queer time travel. Seattle, WA: Contagion Press, 2015. 123-166.

28. Reuters. 'Mass mink graves in Denmark may have soiled groundwater'. 10 December 2020. Available at https://www.reuters.com/article/health-coronavirus-denmark-mink/mass-minkgraves-in-denmark-may-have-soiled-groundwater-report-idUSKBN28K14N. Accessed 15 May 2021.

29.Rousing, Tine, Steen Henrik Møller and Steffen W. Hansen. 'WelFur-mink: on-farm welfare assessment of mink (Neovision vision) - effect of sample size on animal-based measures' (2021). Available at https://www.semanticscholar.org/paper/WelFur-mink\%3A-on-farmwelfare-assessment-of-mink-of-Rousing-

M\%C3\%B81ler/06c5f2db73e2499bfd2b0c238cfa367bf81a3f29. Accessed 12 March 2021.

30. Shakespeare, William. Hamlet, Prince of Denmark. Edited by Philip Edwards. Cambridge: Cambridge University Press, 1985.

31.The Guardian. 'Culled mink rise from the dead to Denmark's horror'. 25 November 2020. Available at https://www.theguardian.com/world/2021/mar/05/pollution-fears-over-minkburied-after-covid-culling-in-denmark. Accessed 16 May 2021.

32.The Guardian. 'Pollution fears over mink buried after Covid in Denmark'. 5 March 2021. Available at https://www.theguardian.com/world/2021/mar/05/pollution-fears-over-minkburied-after-covid-culling-in-denmark. Accessed 16 May 2021.

33.The Local. 'Denmark begins exhumation of four million dead mink'. 13 May 2021. Available at https://www.thelocal.dk/20210513/denmark-begins-exhumation-of-fourmillion-mink-carcasses/. Accessed 15 May 2021.

34.Treton, Danielle. 'La lalalangue'. Insistance 5.1 (2011): 163-9. 
35.Williams, Alex, and Nick Srnicek. '\#Accelerate Manifesto'. Available at https://criticallegalthinking.com/2013/05/14/accelerate-manifesto-for-an-accelerationistpolitics/. Accessed 13 June 2021.

\section{Stink, Therefore I Mink [Duhnesc, deci nurcesc]. Un manifest}

\section{Rezumat}

Recenta exterminare în masă a nurcilor din Danemarca și din alte locuri, ca urmare a contaminării acestora cu o variantă de COVID-19, reprezintă un punct de plecare în revizitarea conversației dintre Derrida și Lacan prin intermediul invocării nurcii din Fiara și suveranul. Din etimologicul 'stink' [putoare, duhoare], atașat lui 'mink' [nurcă] provine un animot, descris cu cerneală nelimitat( $\breve{a})^{*}$ și cu un potențial de a perturba filosofii ale limbajului, de a scrie o replică și de a da o lovitură, așa cum s-a întâmplat recent sub forma multtitudinii de cadavre care reapar în conștiințe. Pe urmele diseminărilor verbale despre vison [vizon] ale lui Derrida și a atribuirii unui „,fel de limbaj” al animalelor de către Lacan în Formațiuni ale inconștientului, acest eseu urmărește cele 17 milioane de nurci programate pentru o dublă extincție, prin inhumare și prin incinerare. Urmează o hauntologie, prefigurată de interesul lui Lacan în „,secreția” blănii, uleiul de nurcă și sensul lor (psihanalitic) și de întâlnirile lui Derrida din 1994 cu neoliberalismul unei cripto-nurci**, Alain Minc.

Nota traducătorului (Arleen Ionescu): traducerea rezumatului în limba română, din păcate, nu poate reda jocurile de cuvinte pe care autoarea le-a tematizat în textul său.

* „descris cu cerneală nelimitat( $(\breve{a})$ ” este o aluzie la volumul lui Jacques Derrida, Limited Inc. (1988 [1977]). ** cripto-nurcă este un cuvânt inventat pe care autoarea îl formează, referindu-se la transcrierea fonetică a numelui lui Alain Minc, "mink" însemnând "nurcă". 